\title{
Miratü'IEbdan Fi Teşrih-i Azaül-İnsan: first printed illustrated anatomy book in Ottoman-Turkish medicine
}

\author{
G. Ortug ${ }^{1}$, A. Ortug ${ }^{2}$, N.K. Kurt ${ }^{3}$ \\ 'Department of Anatomy, School of Medicine, Bahcesehir University, Istanbul, Turkey \\ 2Department of Anatomy, School of Medicine, Istanbul Medipol University, Istanbul, Turkey \\ ${ }^{3}$ Department of History of Medicine and Ethics, Maltepe University School of Medicine, Turkey
}

[Received: 18 January 2018; Accepted: 4 April 2018]

\begin{abstract}
Background: Medical education in Ottoman-Turkish medicine was shaped by the influence of Claudius Galenus (c. 130-c. 210) and Ibn-i Sina (c.980-c. 1037). These teachings were performed in madrasahs until the beginning of the $19^{\text {th }}$ century. Within the scope of master-apprentice relationship, medical training was also given in private clinics. As a result of religious and social pressures on scientific studies, human cadavers were never used because they were considered sacred. For centuries, all books were handwritten in the Ottoman Empire until the first printing press was established in Istanbul during 1726 . However, the first illustrated book on anatomy was not printed until another 100 years later.

Materials and methods: A comparative study was conducted on the anatomical drawings in "Miratü'l Ebdan Fi Teşrih-i Azau'l Insan" (Ataullah ŞM, 17 th), and significance of this book.
\end{abstract}

Results: Forty-six out of 56 figures were received from the book of physician and anatomist Jean Palfin (1650-1730). Remaining 9 figures were cited from author himself as collected from Bernard Siegfried Albinus (1697-1170), Raymond Vieussens (1614-1715), R. Drake (1667-1707), Clopton Havers (1657-1702), Albrecht von Haller (1708-1777), Joseph Guichard Duverney (1648-1730). The figures were drawn exactly the same way with minimal changes. Main text of the book is mostly translation from Italian edition of Bertin and Palfin's Works. The book is not only the first printed anatomical book but also the first printed work in Ottoman-Turkish medicine. Another very significant aspect of the illustrations are perspective drawing figures which differ from miniature style drawings of the past. Conclusions: Şânîzade Ataullah's work has a significant value not only for being the first printed illustrated anatomy book which makes it more approachable but also for providing anatomical drawings as illustrations not as miniature style painting. (Folia Morphol 2018; 77, 4: 764-770)

Keywords: Şânîzade Ataullah Mehmed Efendi, Chani-zadeh, Ottoman-Turkish medicine, history of anatomy

\section{INTRODUCTION}

The invention of the printing press enabled Europe to advance in the science and culture fields many years prior to the Ottoman Empire. The pressure of religious and social doctrines delayed the establishment and use of the printing press until $1726[24,28,29]$.

Address for correspondence: Dr. A. Ortug, Istanbul Medipol University, School of Medicine, Department of Anatomy, Istanbul, Turkey, e-mail: alpenortug@gmail.com 
During this period some medical books were printed. Prior to this period, many significant and influential books in the field of medicine were written in Ottoman state. During the $17^{\text {th }}$ century, the book named "Risale-i Teşrih-i Ebdan" (1632) on human anatomy was authored by Semseddin-i itaki (1572-1632?) and contained two-dimensional miniature style paintings and it was handwritten $[23,24]$. Subsequently, during $16^{\text {th }}\left(17^{\text {th }}\right)$ century, Emir Celebi (? -1638) authored the book named "Enmûzeçi-t Tıb" (1624) which had deep anatomical information but no illustrations [16].

The first printed illustrated book in Ottoman-Turkish medicine was published in 1820 by Şânîzade Mehmet Ataullah Efendi (1771-1826). Illustrations contained in the book were copied from Western anatomists. Some original drawings were altered with additions that were not included in the original copy. According to researches, some of the illustrations contained in this book were copied by an Armenian artist named "Amel-i Agop Erzurumî" $[3,18,25]$.

\section{Who is Şânîzade Ataullah Efendi?}

Born in 1771, in Istanbul, Şânîzade Mehmed Atâullah Efendi (Chani-Zadeh, Mehemmed Ataoollah) was accepted as an influential historical figure in Ottoman-Turkish medical modernisation movement (Fig. 1). He completed his medical and also engineering studies at a madrasah in Istanbul. Although he published medical works, there are no findings of any publications in the field of engineering.

Then as being a son of a hekim bashi/firts physician of the empire, he had a chance to travel to Italy for his further education $[10,36]$. Research indicates that he also studied medicine in Italy and made significant scientific travels to Europe. It seems that during this period he collected main material in Italian, French, and Latin. He studied science in many languages enabling him to be vastly knowledgeable in Western medicine $[2,6]$.

Şânîzade (1771-1826) is regarded as a leading figure in originating new medical information from the Western perspective. He also translated the work of Aloisio Careno of Pavia (1776-1810), a doctor in Vienna, called "Sur la Vaccine" published in 1801 . He was admired and supported by the Sultan II Mahmud (1785-1839) who was instrumental in furthering the renewal of Ottoman state in science. Between 1808 and 1821, he served as a historiographer for Ottoman state. A very well-

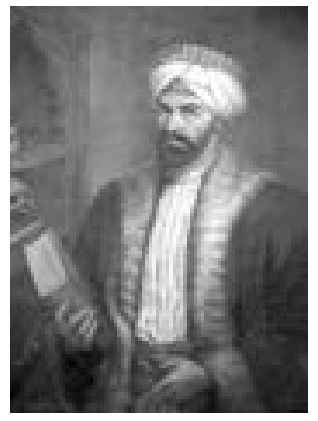

Figure 1. Şânîzade Ataullah Efendi (1771-1826) [5].

known four-volume history book entitled "Şânîzade History" was published in 1820. He died in Tire, a town in Anatolia in 1826.

\section{MATERIALS AND METHODS}

In this research, a comparative study was conducted on the anatomical drawings in "Miratü'l Ebdan Fi Teşrih-i Azau'I Insan" (Ataullah ŞM, 17 ${ }^{\text {th }}$ ), and significance of this book written by Şânîzade Mehmed Ataullah Efendi.

\section{RESULTS}

Şânîzade completed the book 'Hamse-i Şânîzade' (Hamse, The Pentology) as five volumes in 1815 and presented it to Sultan II Mahmud [10, 15]. In 1820, the first three volumes of the book were published as a single volume at Dar't-Tıba'atü'lAmire in Istanbul $[2,6,10,18,27,30,31,35]$. The first volume of these three volumes of the book was named 'Miratü'l Ebdan Fi Teşrih-i Azaül-insan' and contained anatomical information. Its content included bones, muscles, eye anatomy, foetus, brain, veins, nerves and glands [29]. In the second and third volumes, information related to physiology and pathology, respectively [1, 29]. Fourth volume was about surgery and fifth about pharmacology. However, fifth volume had never printed and remained as a handwritten manuscript.

In addition to the Arabic terminology, Latin and Greek phrases are also included in the text in the first volume describing anatomy [29]. It also started a new medical terminology in Turkish [22]. Present-day publications on the content of this book describe it as partially translation and partially original [18]. However, as well as Bianchi's informative work, according to a French publication that introduced the book in 1835, it seems as translation from Bertin and Palfin's works $[10,12]$. 
Table 1. Origins and features of the illustrations in the book. Those marked with an asterisk $\left({ }^{*}\right)$ are those which the writer himself cites

\begin{tabular}{|c|c|c|}
\hline Number of the illustration & Name of the author which image belongs to & Feature of the illustration \\
\hline 20. ve $21 *$ & Bernard Siegfried Albinus (1697-1170) & Skeletal muscles of whole body \\
\hline 49 ve $55 *$ & Raymond Vieussens (1614-1715) & Spinal cord and autonomn nerveous system \\
\hline $50^{*}$ & R. Drake (1667-1707) & Arterial circulation \\
\hline $52^{*}$ & Clapton Havers (1657-1702) & Exit of spinal nerves from spinal cord and meninges of spinal cord \\
\hline 53 ve 54 * & Albrecht von Haller (1708-1777) & Topographic anatomy of the head and neck \\
\hline $56^{*}$ & Joseph Guichard Duverney (1648-1730) & Distribution of facial nerve in face \\
\hline $\begin{array}{l}1-19 \\
23-48 \\
51\end{array}$ & Jean Palfin (1650-1730) & $\begin{array}{c}\text { Surface anatomy of the body } \\
\text { Osteology } \\
\text { Deep thorax and back muscles } \\
\text { Topographic anatomy of the anterior abdominal wall } \\
\text { Gastrointestinal system } \\
\text { Urinary system } \\
\text { Internal genital organs of male and female } \\
\text { Structure of heart } \\
\text { Coronary vessels } \\
\text { Respiratory system organs } \\
\text { Muscles of eye } \\
\text { Sensory organs }\end{array}$ \\
\hline
\end{tabular}

The book has two important aspects. First, it is the first printed work in Ottoman-Turkish medicine. Second, it illustrates the human anatomy in perspective drawing figures which differs from miniature style drawings of the past. This book is considered also as an anatomy atlas containing 56 figure drawings. With these anatomical figures, the book is about 300 pages [6, 29, 30]. In our research, we encountered many Turkish and foreign publications which claim that the images contained in the book are from the books of various Western anatomists chiefly including Vesalius [14, 18, 26, 34, 40]. However, this is not exactly true as 47 of the 56 images contained in the book are identical copies of those in French anatomist Palfin's 'Anatomie Chirurgicale, Ou Description Exacte Des Parties Du Corps Humain, Avec Des Remarques Utiles Aux Chirurgiens dans la Pratique de leur' $[5,33]$. The images in Şânîzade's book mostly follow the same sequence as Palfin's. The images of foetus skeletons, thorax muscles and male and female external genital organs provided by Palfin were not used in Şânîzade's work. Instead of these 9 images, however, those describing all skeletal muscles, the systemic peripheral circulation and the peripheral nervous system from anatomists he himself cites were added [1, 40]. Table 1 indicates the number of plate, originated author and feature of the images.

\section{DISCUSSION}

The evaluation is made under four main titles.

\section{Evaluation of content of the book}

It is mentioned that, in his book that was published in three volumes, Şânîzade combined translations of some works by his Western colleagues and his own experiences. Various sources report that he utilised Italian books [2, 37]. Additionally, according to a French publication introducing this book entitled "Bulletin in Medicine" that was published in 1825, the work is already a translation of the Italian edition of the books by the French anatomists Bertin and Palfin [12]. Sources also mention that he suggested that original French texts must be followed due to the French influence on Italian publications in the subject matter era [21, 37].

It is not mentioned in these sources whether the whole book is a translation or if it contains his own experiences and contributions. So, it is described as a copyrighted work by some. Another significant value of it in terms of Ottoman-Turkish medicine is the fact that the use of modern Turkish medical terminology started with this work for the first time [22]. Provision of Turkish equivalents for Arabic and Persian medical explanations enabled a simplification of language and allowed the book to be comprehendible by general public community. As the works produced until that time were manuscripts written in a heavy Ottoman 


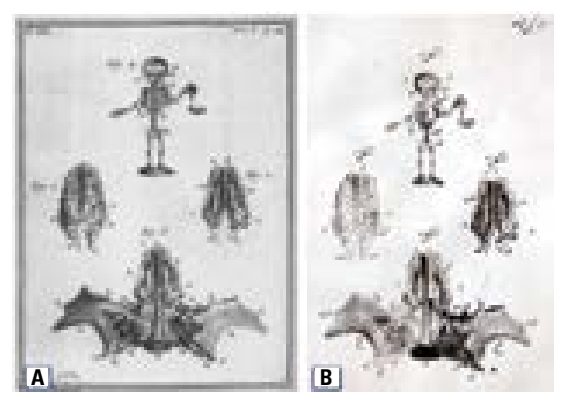

Figure 2. A. Palfin (1650-1730) "Anatomie chirurgicale ou description exacte des parties du corps humain" 1753 [33]; B. Şânîzâde (1771-1826) “Miratü'l Ebdan fi Teşrih-i Azaü'l İnsan”, 1820 [5].

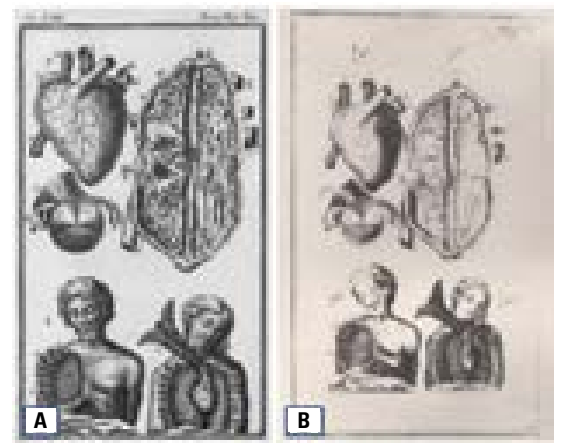

Figure 3. A. Palfin (1650-1730) “Anatomie chirurgicale ou description exacte des parties du corps humain" 1753 [33]; B. Şânîzâde (1771-1826) “Miratü'I Ebdan fi Teşrih-i Azaü'l Insan”, 1820 [5].

Turkish dominated by Arabic and Persian in handwriting, they failed to reach ordinary people.

Compared with Arabic/lslamic works of its time, the work is distinguished by both the accuracy of its knowledge base and also the anatomic details covered [19]. It has been explained that Şânîzade was able to make comparisons and correct some errors thanks to the fact that he had a good command of many foreign languages including Greek and that he received both Ottoman madrasah education and also Western medical education [19].

\section{Evaluation of the images in the book}

Sources emphasise that Şânîzade's book utilises the images from the books of some renowned Western anatomists particularly including Vesalius. However, this judgement is not right to a great extent. Because, 47 of the 56 images in the book are exact copy of a French book named 'Anatomie Chirurgicale, Ou Description Exacte Des Parties Du Corps Humain, Avec Des Remarques Utiles Aux Chirurgiens dans la Pratique de leur' by Jean Palfin (1650-1730) which was published in 1734 and republished and re-edited in the following years by Antoine Petit.

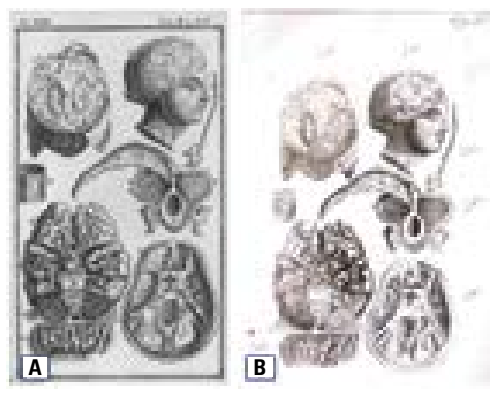

Figure 4. A. Palfin (1650-1730) "Anatomie chirurgicale ou description exacte des parties du corps humain" 1753 [33]; B. Şânîzâde (1771-1826) “Miratü'l Ebdan fi Teşrih-i Azaü'l İnsan”, 1820 [5].
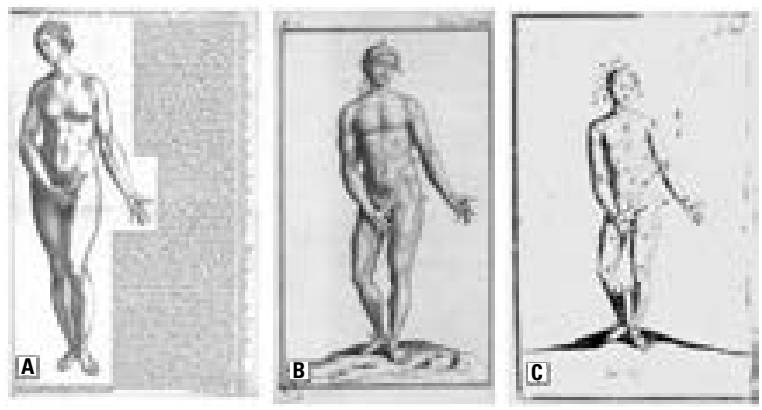

Figure 5. A. Vesalius (1514-1563) "Humani corporis fabrica", 1543 [38]; B. Palfin (1650-1730) "Anatomie chirurgicale ou description exacte des parties du corps humain" 1753 [33]; C. Şânîzâde (1771-1826) “Miratü’l Ebdan fi Teşrih-i Azaü'l İnsan”, 1820 [5].

However, as also explained in Bulletin in Medicine (1825), these images are more indistinct and not professional in terms of visuality [12]. Some of those images were given here for comparison (Figs. 2-4).

As can be seen in Figure 3, even the male and female physical appearance does not resemble those of Anatolian people.

There are also similarities between some of the images belonging to Palfin and those from earlier times (Figs. 5-8). Here it seems to be a characteristic of the period in which it has a similar character and it offers styling and painting.

In Şânîzade's book, absence of male and female external genital organs and foetal skeletal images that are provided by Palfin indicates probable cultural and religious reservations. Yet, there are images with internal genital organs and a small foetus image but those are not understandable from those who are not involved in anatomy or medicine. On the other hand, although Palfin also offered images of the nervous system and the circulatory system, Şânîzade preferred to use images of these from other anatomists (Figs. 9-11; Table 1). Especially the preference for different anatomists for images of different systems shows his 

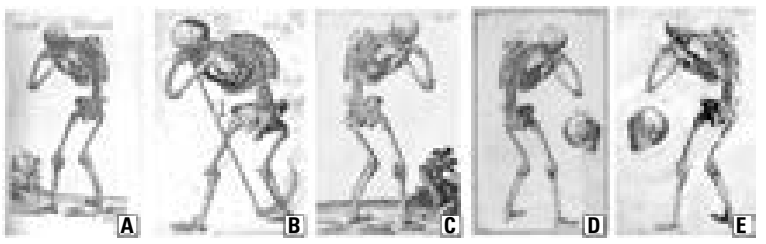

Figure 6. A. Vesalius (1514-1563) "Humani corporis fabrica", 1543 [38]; B. Bauhin (1560-1624) “Theatrum Anatomicum”, 1605 [9]; C. Casserii (1552-1616) “Tabulae Anatomicae", 1632 [13]; D. Palfin (1650-1730) "Anatomie chirurgicale ou description exacte des parties du corps humain" 1753 [33]; E. Şânîzâde (1771-1826) “Miratü'l Ebdan fi Teşrih-i Azaü’l İnsan”, 1820 [5].
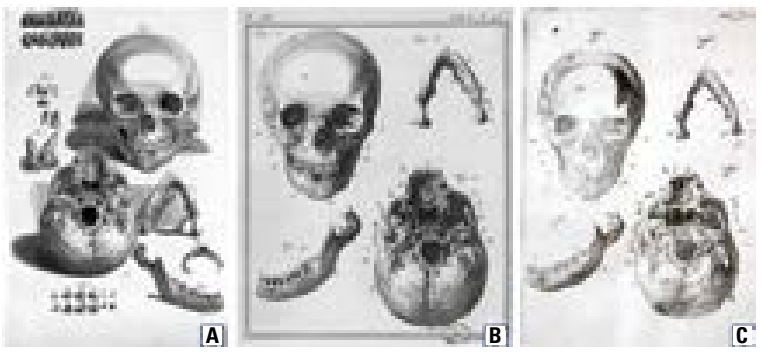

Figure 7. A. Bidloo (1649-1713) "Anatomia Humani Corporis", 1685 [11]; B. Palfin (1650-1730) "Anatomie chirurgicale ou description exacte des parties du corps humain" 1753 [33]; C. Şânîzâde (1771-1826) “Miratü'l Ebdan fi Teşrih-i Azaü'l İnsan”, 1820 [5].
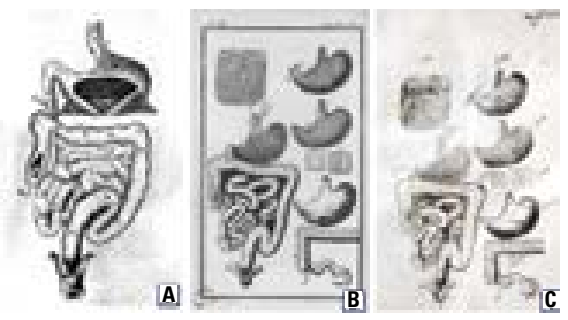

Figure 8. A. Bartholin (1616-1680) "Anatomia reformata", 1655 [8]; B. Palfin (1650-1730) "Anatomie chirurgicale ou description exacte des parties du corps humain" 1753 [33]; C. Şânîzâde (1771-1826) “Miratü'l Ebdan fi Teşrih-i Azaü’l İnsan”, 1820 [5].
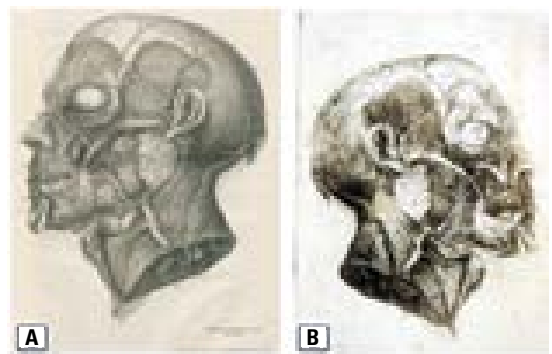

Figure 9. A. Haller (1708-1777) “Icones anatomicae”, 1756 [20]; B. Şânîzâde (1771-1826) “Miratü'l Ebdan fi Teşrih-i Azaü'I İnsan”, 1820 [5].
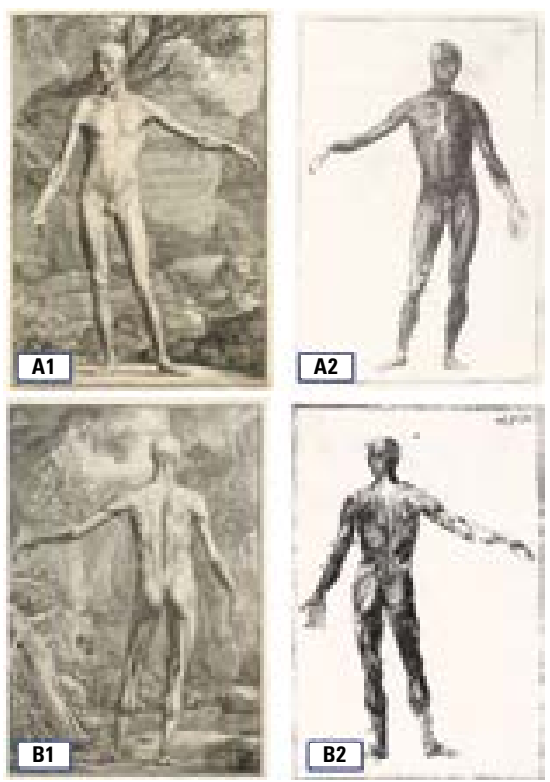

Figure 10. A1, A2. Albinus (1697-1770) “Tabulae sceleti et musculorum corporis humani", 1747 [4]; B1, B2. Şânîzâde (1771-1826) “Miratü’l Ebdan fi Teşrih-i Azaü'l İnsan”, 1820 [5].
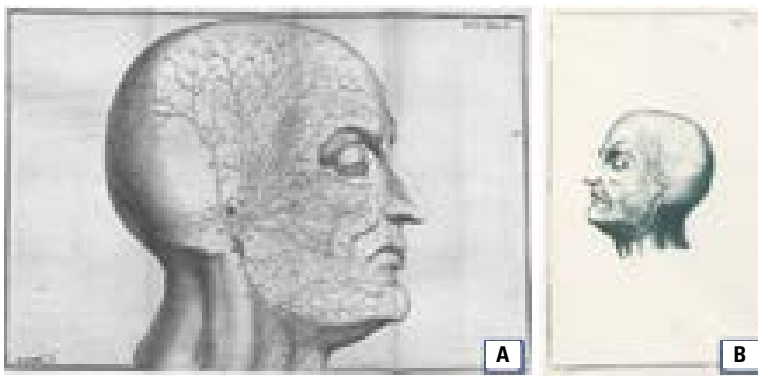

Figure 11. A. Duverney (1648-1730) “Traité de l'organe de l'ouïe: contenant la structure, les usages et les maladies de toutes les parties de l'oreille", 1731 [17]; B. Şânîzâde (1771-1826) “Miratü'l Ebdan fi Teşrih-i Azaü'l İnsan", 1820 [5].

selectivity regarding images and also his command of the old books by Western anatomists.

The common characteristic of all the images is the fact that they maintain their currency today and similar ones are contained in modern anatomy atlases. And once more, this shows the revolutionary aspect of the book especially in the Ottoman-Turkish medicine.

There is also less information about illustrators of the paintings in Şânîzade's book (1771-1826). It is stated that, some of the painting were signed as an Armenian painter named "Amel-i Agop Erzurum", an Ottoman Empire citizen originated from Erzurum city $[3,18,25]$. However, no information resides about who was this artist or whether he illustrated any other anatomy drawings or not.' The writer mentioned the source of some of the images he used [40]. These 
are listed in Table 1. However, interestingly the name Palfin is not cited although many of his images are used identically.

\section{The influence of the book on the Ottoman-Turkish medicine}

Şânîzade is also considered in the Ottoman medicine to be the person who built the bridge between the old traditional medicine and the modern or new medicine [7]. Until that time, the Islamic medicine had followed the teachings of Galen and then Ibni-Sina that contained mostly inaccurate descriptions based on animal rather than human dissections. The change started in Europe especially with Vesalius, but it took long years for the influence of this to reach the Ottoman-Turkish medicine. This point constitutes the most important characteristic of this book by Şânîzade, which is considered to be a copyrighted work by some sources. Although there is an interesting $17^{\text {th }}$ century book by Semsettin Itaki that blended the teachings of Ibni Sina with the Western medicine, it failed to make the expected influence especially in terms of the modern development of anatomy in the Ottoman-Turkish medicine. Şânîzade is regarded as the person who introduced modern anatomy to the Ottoman medicine [7]. Hence the comments to the effect that he practically ended an era and started a new one in terms of Ottoman medicine [14].

In this context, especially the atlas-type, non-miniature, three-dimensional and in-depth images in the book, a majority of which maintain their actuality and currency in today's anatomy, demonstrate the level reached by the Ottoman-Turkish anatomy. As image is an art that is avoided in the Islamic world especially due to religious beliefs, it was not possible to show actual images of theoretical information, and efforts were taken to utilise two-dimensional miniatures for this purpose. However, miniature drawings were extremely primitive and superficial.

Another point here is that although the name of the book includes the word 'teşrih' (dissection), the dissection images contained in the book cannot have been produced by themselves because during this period of Ottoman-Turkish medicine, it is known that human dissections had not been carried out. Great pressure was exerted on those who attempted to perform human cadaver dissections. It was not until 1841 that dissection in Ottoman-Turkish medicine was permitted. Serious reforms were initiated by doctor Karl Ambros Bernard (1808-1844), who was invited as a teacher to Galatasaray Medical School in Istanbul from Austria. His efforts on initiating a new medical training curriculum and dissection resulted in the first human dissection not by himself, but by Austrian doctor Sigmund Spitzer (1813-1895), who came to Istanbul to teach at Galatasaray Medical School [29, $32,35]$. As seen, there is a chronological difference between the publication of the book and the official start of dissection. Therefore, it is an object of interest why the name 'teşrih' (dissection) was used in the title of the book at a time when dissection was forbidden. However, it is likely that he used this name because he translated Palfin's book, the title of which included the phrase "Anatomie Chirurgicale" (Surgical Anatomy).

\section{Influences, evaluation and results of the book in terms of foreigners}

A copy of the book was sent by the Ottoman Sul$\tan$ Mahmud II to the French Embassy. In the embassy, it aroused the attraction of Thomas-Xavier Bianchi (1783-1864), who was a French orientalist, and sent to France as an evidence of the change of mentality in the Ottoman Empire [26]. Another important point here is the fact that Bianchi recommended this book for learning Turkish to those physicians who were to serve in Oriental states, because the book contained Turkish medical terms with their Arabic and Persian synonyms $[10,18]$

Upon a very positive criticism published by Bianchi (1821), the book also became popular in Europe and was praised by French readers [39]. In his comments, Bianchi stated that France was honoured by the contribution made to the Ottoman civilising process by this work that drew upon French works [39]. As a member of the body of 'Oolemas' (religious official), Şânîzade's deep engagement in science and his anatomic interpretations attracted the attention of his European colleagues [39]. The book was followed in Europe not because of its content but of the fact that the Ottoman-Turkish medicine was following civilisation and the Western medicine. Seriously lacking anatomical knowledge for a long time due to religious prohibitions, the Ottoman-Turkish medicine's catching up with and following the current medical knowledge was appreciated.

\section{CONCLUSIONS}

It is known that the $19^{\text {th }}$ century Ottoman Empire sought 'new knowledge' in many areas and tried to modernise. The progress and improvement in the Ottoman-Turkish medicine emerged in that time period. Although, for European medicine this important work 
by Şânîzade Ataullah was overshadowed by debates about whether it was a translation or an original work, it is significant for ending an era and starting a new one from the viewpoint of Turkish medicine. It made a breakthrough not only by the fact that it reached all sections of the society as the first printed book but also that it brought the novelty of depicting human body with actual images at a time when images were forbidden.

\section{Acknowledgements}

The authors wish to thank Gulhan Akturk, BA, MA, M.Ed. in RI, USA for editing the manuscripts and comments that greatly improved the manuscript.

\section{REFERENCES}

1. Aciduman A, Er U, Şimsek S. Şânîzâde Atâullah Mehmed Efendi ve Mirâtü'l-Ebdân fî Teşrîh-i A'zâi'l-İnsân Adlı Eserindeki Santral Sinir Sistemi Anatomisi ile Ilgili Bölümler. Turkiye Klinikleri Journal of Medical Ethics-Law and History. 2009; 17(2): 71-86.

2. Aciduman A, Arda B. Physician-anatomists of Italy in Şānīzāde Mehmed Atāullah Efendi's work Mir'āt al-abdān (Mirror of bodies). Clin Anat. 2014; 27(6): 808-814, doi: 10.1002/ca.22400, indexed in Pubmed: 24753269.

3. Akar M. Tıp Eğitiminde Görsel Sanatın Etkisi. Sosyoloji Derg. 2015; 30(1): 355-380.

4. Albinus BS. Tabulae sceleti et musculorum corporis humani, Leyden. 1747.

5. Ataullah ŞM. Miratu'l Ebdan fi Teşrih-i Azau'I Insan. H. 1235. Ankara Milli Kütüphane No. 1946 B; 52: 1235.

6. Aycan K, Öztürk M, Öztürk N. Miratu'l Ebdan fi Teşrih-i azau'I insan. Şânîzade Ataullah Efendi (1771- 1826). Erciyes Üniversitesi Gevher Nesibe Tıp Tarihi Enstitüsü, Kayseri. 1989: 29-43.

7. Baran Y. The Leech Craze: The Medicinal Use and Commodification of Leeches in the Nineteenth Century Ottoman Empire. Tarih, Boğaziçi University Department of History. 2013: 49-75.

8. Bartholin T Anatomia... reformata. Hagae-Comitis. 1655.

9. Bauhin C. Theatrum Anatomicum. Frankfurt am Main. 1605.

10. Bianchi TX. Notice sur le premier ouvrage d'anatomie et de medecine imprime en turc, a Constantinople, en 1820, intitule: Miroir des corps dans l'anatomie de l'homme. LT Cellot. 1821.

11. Bidlioo G. Ontleding des Menschelyken Lichaams. Amsterdam. 1690.

12. Bulletin des sciences médicales: troisième section du Bulletin universel des sciences et de l'industrie, Paris. 1825: 209-212.

13. Casserii (ii) G. Tabulae anatomicae LXXIIX. Frankfurt am Main. 1632.

14. de Divitiis O, Elefante A, de Divitiis E. Historic background of spinal disorders. World Neurosurg. 2013; 79(1): 91-94, doi: 10.1016/j.wneu.2012.04.019, indexed in Pubmed: 22548890.

15. Dilemre M. Türkiyede basılı ilk anatomi kitabımız. Ankara Üniv Tıp Fak Mecm. 1946: 69-71.

16. Çelebi EM. Enmûzeç-i Tıb. Süleymaniye Library Esad Efendi Nr. 2457/1 istanbul \& British Museum Or. nr. 7282/1 Londra. : 17th.

17. Duverney, J. G. Traité de l'organe de l'ouïe: contenant la structure, les usages et les maladies de toutes les parties de l'oreille. Langerak. 1731.
18. Erdoğan M. Şani-zade Mehmed Ataullah Efendi (Hayatı, kişiliği, eserleri, etkileri). Master's Thesis. ESOGÜ, Sosyal Bilimler Enstitüs. 2016.

19. Goodrich JT. The contributions of an Ottoman Empire polyglot to spinal anatomy: an interesting historical insight into a little known period in the history of neurosurgery. World Neurosurg. 2013; 79(1): 95-96, doi: 10.1016/j. wneu.2012.04.022, indexed in Pubmed: 22548880.

20. Haller A. Icones anatomicae Gottingen. 1756.

21. Hanoğlu L. http://www.sdplatform.com/Dergi/327/Tababette-gelenekten-kopus-ve-Şânîzade-Ataullah.aspx.

22. Huff TE. Science and Metaphysics in the Three Religions of the Book. Intellectual Discourse. 2000; 8(2): 173-198.

23. Itaki Ş. Risale-i Teşrih-i Ebdan. Süleymaniye Library, Hüsrevpaşa Nr. 464, İstanbul. 17th.

24. Kahya E. Şemseddîn-i İtâki'nin Resimli Anatomi Kitabı. Ankara. 1996.

25. Kayaalp E. Granting historocity to scientific objects: the analysis of the life history of The outermost order of the muscle, bock view. Osmanlı Bilimi Araştırmaları. 2016; 17(2): 27-41.

26. Kazancıgil A, Zülfikar BX. Yüzyılda Osmanlı İmparatorluğunda Anatomi. Özel Yayınlar istanbul. 1991: 14-16.

27. Köker AH. Şani-Zade'nin Hayatı ve Eserleri. Erciyes Üniv. Gevher Nesibe Tıp Tarihi Enstitüsü, No. 5 Kayseri. 1989: $1-11$.

28. Kut T, Türe F. Yazmadan Basmaya: Müteferrika, Mühendishane. İstanbul. 1996: 3-12.

29. Mesut R. Osmanlı döneminde Türk anatomi bilimi ve anatomi öğretimi. Morfoloji Derg. 1997; 7: 11-14.

30. Nafiz M. Basma Ilk Türk Tıb Kitabı ve Şânîzade Ataullah. Dirim, 1936; 1 1(144-6. : 180-182.

31. Nüzhet S. Basma ilk Türk Tıp Kitabı. Şânîzade Teşrihi. Poliklinik. 1935; 3(5-29): 147-149.

32. Ortuğ G, Yücel $F, A y H$. The role of Austrian physicians and Prof. Joseph Hyrtl (1810-1894) on modernization of Ottoman-Turkish medicine. Ann Anat. 2003; 185(6): 593-596, doi: 10.1016/S0940-9602(03)80134-6, indexed in Pubmed: 14704006.

33. Palfijn J. Anatomie chirurgicale ou description exacte des parties du corps humain", Paris, La veuve Cavelier et fils, 1753, 2 volumes. Paris. Bibliothèque du Musée de l'Homme.

34. Russell G. The Owl and the Pussy Cat: The Process of Cultural Transmission in Anatomical Illustration. In Transfer of Modern Science and Technology to the Muslim World, ed. E insanoğlu, Istanbul. IRCICA. 1992.

35. Şehsuvaroğlu B. Bizde anatomi öğretimine dair. İst Tıp Fak Mecm. 2003; 15: 365-412.

36. The Monthly Magazine: Or, British Register. London. $1825 ; 60$.

37. Ulman YI. Portraits of Italians in health affairs in 19th century Istanbul: Dr. Castaldi, Pharmacist A. Calleja, Midwife Messani. Oriente Moderno. 2008; 88: 135-149.

38. Vesalius A Humani corporis fabrica Basel. 1543.

39. Yalçinkaya MA. Learned Patriots: Debating Science, State ve Society in the Nineteenth-Century Ottoman Empire. University of Chicago Press. 2015; 33.

40. Zülfikar B. Şânîzade Mehmet Ataullah: Hayatı ve Eserleri. In Osmanlı İmparatorluğunda XIX. Yuzyılda Anatomi, ed. A. Kazancigil, Istanbul: Özel Yayınlar. 1991. 